\title{
Mechanistic studies on $\delta$-aminolevulinic acid uptake and efflux in a mammary adenocarcinoma cell line
}

\author{
S Correa García', A Casas', C Perotti', A Batlle*,I and M Bermúdez Moretti' \\ 'Centro de Investigaciones sobre Porfirinas y Porfirias (CIPYP), FCEN, University of Buenos Aires, Argentina; CONICET, Ciudad Universitaria, Pabellón II, \\ $2^{\circ}$ Piso, Buenos Aires, 1428 Argentina
}

\begin{abstract}
$\delta$-aminolevulinic acid (ALA) is the precursor in the biosynthesis of porphyrins. The knowledge of both the regulation of ALA entrance and efflux from the cells and the control of porphyrin biosynthesis is essential to improve ALA-mediated photodynamic therapy. In this work, we studied the regulation of ALA uptake and efflux by endogenously accumulated ALA and/or porphyrins in murine mammary adenocarcinoma cells. Under our set of conditions, the haem synthesis inhibitor succinyl acetone completely prevented porphobilinogen and porphyrin synthesis from ALA, and led to an increase in the intracellular ALA pool. However, neither intracellular ALA nor porphyrin pools regulate ALA uptake or efflux during the first 15 min of the process. Based on temperature dependence data, ALA but not $\gamma$-aminobutyric acid (GABA) efflux is mediated by a diffusion mechanism. Moreover, the addition of extracellular GABA not only did not influence the rate of ALA efflux but on the contrary it affected ALA uptake, showing the contribution of a saturable mechanism for the uptake, but not for the efflux of ALA from the cells.

British Journal of Cancer (2003) 89, 173 - 177. doi:I0.1038/sj.bjc.6601066 www.bjcancer.com

(C) 2003 Cancer Research UK
\end{abstract}

Keywords: $\delta$-aminolevulinic acid; photodynamic therapy; ALA uptake; ALA efflux

$\delta$-aminolevulinic acid (ALA) is the precursor in the biosynthesis of porphyrins, which in association with several proteins are essential for the utilisation and metabolism of oxygen. The first step of the porphyrin biosynthetic pathway is the synthesis of ALA by a condensation reaction between succinyl CoA and glycine, catalysed by the enzyme ALA synthase. This enzyme is rate limiting, tightly regulated by feedback inhibition (Rimington, 1966). The second rate limiting step in haem synthesis is the incorporation of ferrous iron into protoporphyrin IX (PPIX), a reaction catalysed by the enzyme ferrochelatase. Owing to this slow conversion of PPIX to haem (Pottier et al, 1986) when exogenous ALA is administered, high tissue levels of porphyrin intermediates are found (Malik and Djaldetti, 1979; Sinna et al, 1981).

Photodynamic therapy (PDT) is a nonthermal technique for inducing tissue damage with light following administration of a light-activated photosensitising drug that can be selectively retained in malignant or diseased lesions relative to normal adjacent tissue (Dougherty et al, 1978). In addition, the fluorescence of photosensitising chromophores has been exploited for the visualisation and diagnosis of early-stage superficial cancers (Kriegmair et al, 1996). It has been demonstrated that sufficient PPIX, a potent photosensitiser, is synthesised by exogenous ALA administration to produce a photodynamic effect following exposure to light (Kennedy et al, 1990; Fukuda et al, 1993a).

ALA-induced PPIX accumulation has been shown to be preferentially greater in certain tumoral cells (Navone et al, 1988), primarily due to the reduced activity of ferroquelatase and a relative enhancement of porphobilinogen (PBG) deaminase

*Correspondence: Professor A Batlle, Viamonte I88I, IOA, CI056ABA, Buenos Aires, Argentina; E-mail: batlle@mail.retina.ar

Received 30 January 2003; revised 4 April 2003; accepted 29 April 2003 activity in these cells (Navone et al, 1991). The success of ALAmediated photosensitisation will depend on an efficient ALA uptake, a low ALA efflux and an efficient conversion of ALA into porphyrins.

Several reports regarding ALA uptake systems have appeared. Thus, some authors demonstrated that ALA is taken up through the di- and tripeptide transporters PEPT1 and PEPT2 (Döring et al, 1998; Novotny et al, 2000; Whitaker et al, 2000). Other authors reported that BETA transporters are involved in ALA transport (Rud et al, 2000). The BETA transporter family comprise GAT-1 to GAT-3, BGT-1 and TAUT transport systems (Palacín et al, 1998). Using murine mammary adenocarcinoma cultured cells, we have recently demonstrated that ALA is incorporated by two different processes (Bermúdez Moretti et al, 2002). One of these processes is passive diffusion that is significant at shorter incubation intervals. The other is an active transport system that becomes very important after the first $15 \mathrm{~min}$ of incubation. The latter system is mediated by one of the BETA transporters, very likely GAT-2 (Bermúdez Moretti et al, 2002).

The knowledge of both the regulation of ALA entrance into the cells and the control of porphyrin biosynthesis is essential to improve ALA-mediated PDT. In this work, we studied the regulation of ALA uptake by endogenously accumulated ALA and/or porphyrins in murine mammary adenocarcinoma cells. We have also determined the nature of the ALA efflux process.

\section{MATERIALS AND METHODS}

\section{Cell line and cell culture}

Cell line LM3 (Werbajh et al, 1998) derived from the murine mammary adenocarcinoma M3 was cultured in minimum essential Eagle's medium, supplemented with $2 \mathrm{~mm}$ L-glutamine, $40 \mu \mathrm{g}$ 
gentamycin $\mathrm{ml}^{-1}$ and 5\% fetal bovine serum, and incubated at $37^{\circ} \mathrm{C}$ in an atmosphere containing $5 \% \quad \mathrm{CO}_{2}$. A total of $3.5 \times 10^{4}$ cells well $^{-1}$ were seeded into 24 -well plates and the medium was renewed $24 \mathrm{~h}$ before the experiment.

\section{Chemicals}

$\left[4-{ }^{14} \mathrm{C}\right]$ ALA hydrochloride and $\left[{ }^{14} \mathrm{C}(\mathrm{U})\right] \gamma$-aminobutyric acid (GABA) were obtained from New England Nuclear, ALA, GABA, succinyl acetone (SA) and metabolic inhibitors were obtained from Sigma Chemical Co., St Louis, USA. Other chemicals were of analytical grade.

\section{ALA and GABA preparation}

Unlabelled ALA or GABA were dissolved in phosphate-buffered saline (PBS) and $\mathrm{pH}$ was adjusted to 7.4 with $\mathrm{NaOH}$. $\left[{ }^{14} \mathrm{C}\right] \mathrm{ALA}$ and $\left[{ }^{14} \mathrm{C}\right] \mathrm{GABA}$ were added so that the final solution contained 0.0222 and $0.0111 \mathrm{MBq} \mathrm{ml}^{-1}$, respectively.

\section{Uptake measurements}

Uptake measurements were performed $72 \mathrm{~h}$ after seeding, when the cells were nearly confluent. The cells were washed twice with $0.5 \mathrm{ml}$ PBS $-0.1 \%$ glucose preheated at $37^{\circ} \mathrm{C}$ and incubated with $0.3 \mathrm{ml}$ radiolabelled $0.6 \mathrm{~mm}$ ALA or GABA prepared in PBS $-0.1 \%$ glucose at $37^{\circ} \mathrm{C}$. At the indicated times, the reaction was stopped by washing the cells four times with $0.5 \mathrm{ml}$ ice-cold PBS containing either $1 \mathrm{~mm}$ ALA or $1 \mathrm{~mm}$ GABA to remove nonspecific binding. Then the cells were disrupted in $0.1 \mathrm{~mm} \mathrm{NaOH}$ and transferred to vials containing scintillation fluid (OptiPhase-Hisafe 3, PerkinElmer, England). The radioactive content of the samples was determined.

\section{Efflux experiments}

The cells were loaded with $0.6 \mathrm{~mm}{ }^{14} \mathrm{C}$-ALA or ${ }^{14} \mathrm{C}$-GABA for $15 \mathrm{~min}$, washed four times with PBS containing either $1 \mathrm{mM}$ ALA or $1 \mathrm{mM}$ GABA to remove nonspecific binding and further incubated with $\mathrm{PBS}$ at $37^{\circ} \mathrm{C}$. Radioactivity within the cells and in the medium was measured at different times of incubation, after adding $0.1 \mathrm{~mm}$ $\mathrm{NaOH}$.

\section{ALA and PBG determinations}

The cells were seeded in $100 \mathrm{~mm}$ dishes. After $72 \mathrm{~h}$, the medium was removed and the cells were exposed for $3 \mathrm{~h}$ to $0.6 \mathrm{~mm}$ ALA in a medium without serum. Afterwards, the cells were washed four times with PBS and 5\% TCA was added. After scrapping, the cells were centrifuged and the supernatant was employed for ALA and PBG determinations. Modifications of the Mauzerall and Granick (1956) method were used. Briefly, for ALA determination, a condensation reaction was developed in the presence of acetyl acetone and the resulting pyrroles were quantified by addition of the Ehrlich reactive. For PBG determination, the Ehrlich reactive was added to the deproteinised TCA supernatant. ALA values were obtained by subtracting PBG values to the total condensed pyrroles.

\section{Porphyrin synthesis}

Porphyrins accumulated within the cells were extracted twice with $5 \% \mathrm{HCl}$, leaving the cells standing for $30 \mathrm{~min}$ in the presence of the acid at $37^{\circ} \mathrm{C}$. For media determinations, $5 \% \mathrm{HCl}$ was added and measured directly. These conditions proved to be optimal for total PPIX extraction. The excitation and emission wavelengths of light used producing the highest fluorescence were 406 and $604 \mathrm{~nm}$, respectively. PPIX (Porphyrin Products, Logan, UT, USA) was used as a reference standard. All the experiments were performed at $0.6 \mathrm{~mm}$ ALA, because porphyrin synthesis is saturated at this concentration.

\section{Cell number}

The number of cells seeded per well and employed for the calculations were determined by counting viable cells with the Trypan blue-exclusion method.

\section{Statistic analysis}

Quadruplicates were run for each point in every experiment and the values presented are the average of three experiments (mean \pm s.d.). The deviation of these values from the mean was less than $15 \%$. A paired Student's $t$-test was used to determine statistical significance between means. $P$ values $<0.05$ were considered significant.

\section{RESULTS}

Cells were incubated with $0.6 \mathrm{~mm}$ ALA in the presence or absence of $0.5 \mathrm{~mm} \mathrm{SA}$ for $3 \mathrm{~h}$, then ALA, PBG and porphyrins were measured (Table 1). Upon exposure to $0.5 \mathrm{~mm}$ SA, PBG and porphyrin biosynthesis is completely eliminated. The presence of a higher intracellular pool of ALA ( $105.4 \pm 7.1 \mathrm{pmol} 10^{-5}$ cells $)$ is also evidenced after SA exposure. At $3 \mathrm{~h}$ after incubation with $0.6 \mathrm{~mm}$ ALA in the absence of SA, the intracellular ALA is almost completely consumed and $15.1 \pm 1.1 \mathrm{pmol} \mathrm{PBG} 10^{-5}$ cells and $13.0 \pm 0.7$ pmol porphyrin $10^{-5}$ cells are formed.

In Figure 1A, ALA uptake was measured in cells treated with SA. We choose $0.1 \mathrm{~mm}$ ALA for this experiment to minimize ALA conversion (Bermúdez Moretti et al, 2002). When the cells were preincubated for $20 \mathrm{~min}$ with $0.5 \mathrm{~mm} \mathrm{SA}$ and this compound was withdrawn before adding ${ }^{14} \mathrm{C}$-ALA, ALA incorporation is similar to that found in control cells. Interestingly, the presence of SA during the whole uptake assay does not modify ALA uptake.

Similarly, Figure 1B shows the effect of SA on GABA transport. Again, there are no changes in GABA incorporation driven by the presence of SA before or during the uptake assay.

In another set of experiments (data not shown), cells treated with $0.5 \mathrm{~mm}$ SA or not were preincubated with $0.6 \mathrm{~mm}$ ALA for 15, 60 or $180 \mathrm{~min}$ before measuring ALA uptake in order to achieve increasing intracellular ALA or porphyrin pools. It was found that initial ALA uptake rates remain constant $(0.113 \pm 0.015 \mathrm{pmol}$ ALA $10^{-5}$ cells min $^{-1}$ ).

In Table 2, we studied the dependence on temperature of ALA and GABA efflux. A $32 \%$ efflux of ALA is detected at $37^{\circ} \mathrm{C}$ and similar results were obtained when it was measured at $0^{\circ} \mathrm{C}$. In contrast, GABA efflux decreases significantly to $18 \%$ when the temperature is lowered to $0^{\circ} \mathrm{C}$.

Table 3 shows the results of ALA and porphyrin efflux in the presence or absence of SA. After 15 min of preloading with ALA, in the absence of SA, a complete conversion of ALA into porphyrins

Table I Intracellular pools of ALA, PBG and porphyrins

\begin{tabular}{lccc}
\hline & -ALA-SA & +ALA-SA & +ALA+SA \\
\hline ALA (pmol 10 $0^{-5}$ cell) & ND & $13.05 \pm 0.90$ & $105.4 \pm 7.1$ \\
PBG (pmol 10 $0^{-5}$ cell) & ND & $15.12 \pm 1.10$ & ND \\
Porphyrins(pmol $10^{-5}$ cell) & $0.56 \pm 0.02$ & $13.01 \pm 0.70$ & $0.38 \pm 0.02$ \\
\hline
\end{tabular}

Cells were exposed for $3 \mathrm{~h}$ to $0.6 \mathrm{mM}$ ALA in the presence or absence of $0.5 \mathrm{~mm} \mathrm{SA}$ in a medium without serum. Afterwards, ALA, PBG and porphyrins were determined according to the procedures described in Materials and Methods. -ALA+SA controls (cells in the presence of SA without exposure to ALA) have been subtracted from +ALA+SA values. ND: nondetectable by this method. 
A

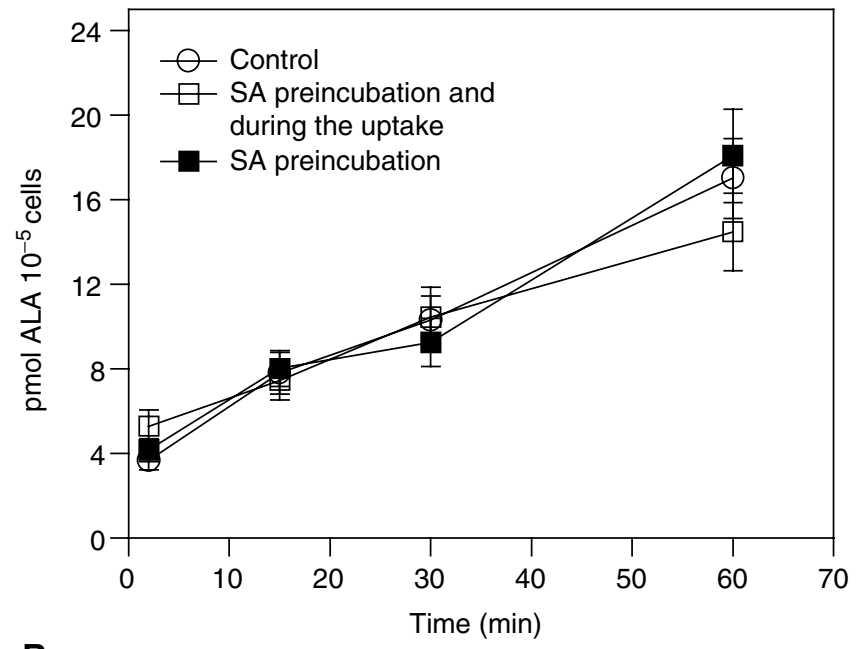

B

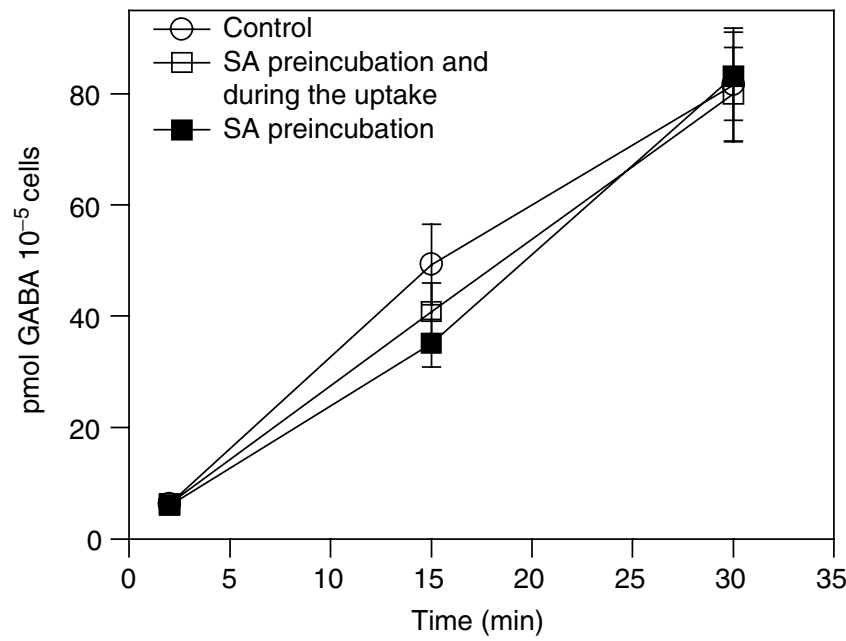

Figure I ALA and GABA uptake in the presence of the haem inhibitor SA. Cells were preincubated with $0.5 \mathrm{mM} \mathrm{SA}$ and $0.1 \mathrm{mM}{ }^{14} \mathrm{C}$-ALA $(\mathbf{A})$ or GABA (B) uptake was measured in the presence or absence of SA. Control, classical ALA uptake $(n=4)$.

is already observed at $60 \mathrm{~min}$, and under these conditions, $15 \%$ of the intracellular tetrapyrrole accumulation is released to the medium. The same pattern is observed at longer periods (180 min). When porphyrin synthesis is prevented by SA exposure, only basal
Table 2 Dependence of ALA and GABA efflux on temperature

\begin{tabular}{lcc}
\hline & \multicolumn{3}{c}{ \% of release } \\
\cline { 2 - 3 } Efflux of & $\mathbf{3 7 ^ { \circ } \mathbf { C }}$ & $\mathbf{0}^{\circ} \mathbf{C}$ \\
\hline ALA & 32 & 31 \\
GABA & 35 & 18 \\
\hline
\end{tabular}

Cells were preloaded for 15 min with $0.6 \mathrm{~mm}{ }^{14} \mathrm{C}$-ALA or GABA, washed with PBS containing either ALA or GABA, respectively, and further incubated for 15 min at 37 or $0^{\circ} \mathrm{C}$. ALA or GABA released to the medium was calculated as a percentage of intracellular radioactivity at $0 \mathrm{~min}$ after ALA loading (initial intracellular pools).

levels of tetrapyrroles are detected together with an intracellular ALA pool.

We expressed as ALA + PBG, the result of the subtraction of porphyrins from the total radiolabelled content, because at these times, we are in the presence of ALA metabolisation in the case of + ALA + SA. Efflux of ALA/PBG to the medium is significantly higher in the presence of SA both at 60 and 180 min of incubation.

Table 4 shows porphyrin synthesis in cells exposed to ALA and GABA. Intracellular porphyrins as well as porphyrins released to the medium are $20 \%$ lower after coincubation with an equimolar GABA concentration (ALA + GABA). When GABA is added after withdrawal of ALA ( + ALA $\rightarrow$ GABA), porphyrin values are not affected, showing that GABA does not modify ALA efflux, at least to the extent of modifying porphyrin synthesis. These results correlate well with an unchanged rate of ${ }^{14} \mathrm{C}$-ALA efflux upon exposure to GABA or ALA after ALA preloading (data not depicted). As expected, further incubation with ALA for $3 \mathrm{~h}$ $(+$ ALA $\rightarrow$ ALA) correlates with an increase in tetrapyrrole formation.

\section{DISCUSSION}

To determine whether intracellular accumulated ALA affects its transport process in murine mammary adenocarcinoma cells, ALA metabolisation was prevented using SA, a specific competitive inhibitor of ALA-dehydratase (Ebert et al, 1979). This enzyme catalyses the condensation of two molecules of ALA to form PBG, the pyrrolic precursor of porphyrins. We proved that under our set of conditions (Table 1), SA completely eliminates PBG and porphyrin synthesis from ALA in this adenocarcinoma cell line. The presence of the inhibitor also leads to an increase of the intracellular ALA pool.

After $3 \mathrm{~h}$ of ALA exposure, in the absence of SA, $13.0 \pm 0.7 \mathrm{pmol}$ porphyrin $10^{-5}$ cells were synthesised. A linear increase in

Table 3 ALA and porphyrin efflux in the presence of the haem synthesis inhibitor SA

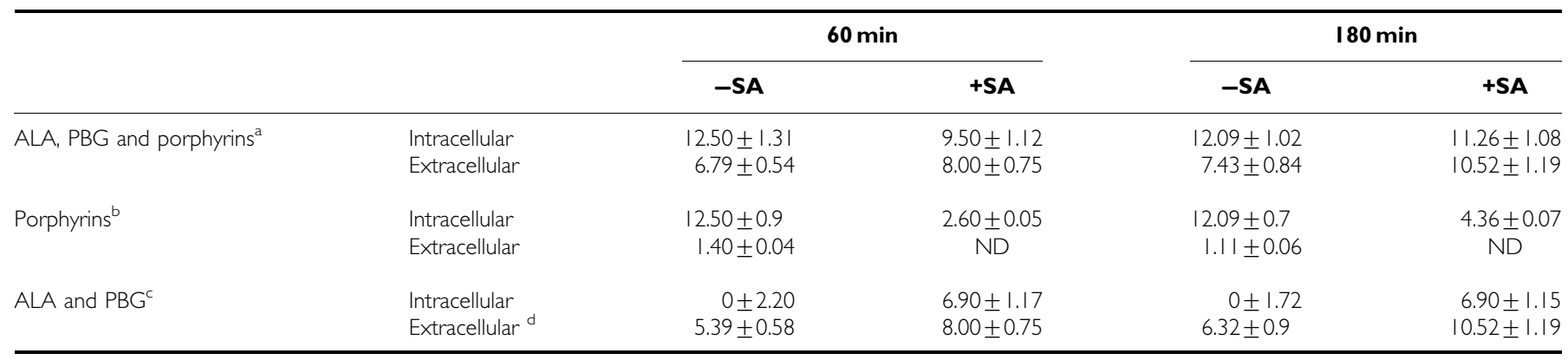

Cells were preloaded for $15 \mathrm{~min}$ with $0.6 \mathrm{mM}{ }^{14} \mathrm{C}$-ALA, washed with PBS and further incubated for 60 and 180 min at $37^{\circ} \mathrm{C}$. Intracellular and extracellular radioactivity was quantified. In addition, porphyrins were quantified spectrophotometrically and expressed per $10^{5}$ cells. In +SA experiments, $0.5 \mathrm{~mm}$ of the haem synthesis inhibitor was present during the preload and efflux incubations.

${ }^{a}$ All expressed as pmol ${ }^{14} \mathrm{C}$-ALA, calculated as the addition of both intracellular and extracellular radioactivity. ${ }^{b}$ pmol ALA converted into porphyrins. ${ }^{\circ}$ Expressed as pmol ALA calculated subtracting ${ }^{b}$ from ${ }^{a}$, intracellular and extracellular, respectively. ${ }^{d} P<0.005$. ND: nondetectable by this method. 
Table 4 Porphyrin synthesis in cells exposed to ALA and GABA

\begin{tabular}{|c|c|c|}
\hline & $\begin{array}{l}\text { pmol intracellular } \\
\text { porphyrin } 10^{-5} \text { cells }\end{array}$ & $\begin{array}{l}\text { pmol extracellular } \\
\text { porphyrin } 10^{-5} \text { cells }\end{array}$ \\
\hline $\begin{array}{l}-\mathrm{ALA}-\mathrm{GABA} \\
+\mathrm{ALA} \\
+\mathrm{ALA}+\mathrm{GABA} \\
+\mathrm{ALA} \rightarrow \mathrm{GABA} \\
+\mathrm{ALA} \rightarrow \mathrm{ALA}\end{array}$ & $\begin{array}{r}0.56 \pm 0.02 \\
2.10 \pm 0.03 \\
1.72 \pm 0.05 \\
2.10 \pm 0.04 \\
9.8 \pm 0.08\end{array}$ & $\begin{array}{l}0.50 \pm 0.02 \\
1.02 \pm 0.05 \\
0.85 \pm 0.09 \\
0.84 \pm 0.04 \\
1.68 \pm 0.05\end{array}$ \\
\hline
\end{tabular}

Cells were loaded by 15 min exposure to $0.6 \mathrm{mM}$ ALA in PBS (+ALA); or with ALA and $0.6 \mathrm{mM}$ GABA (+ALA+GABA). Afterwards, the cells were washed four times and further incubated for $3 \mathrm{~h}$ in PBS. +ALA $\rightarrow$ ALA and $+A L A \rightarrow$ GABA correspond to cells preloaded for $15 \mathrm{~min}$ with ALA, but were further exposed for $3 \mathrm{~h}$ either to $0.6 \mathrm{mM}$ ALA or GABA, respectively. Porphyrins were extracted and quantified according to the procedures described in Materials and Methods.

porphyrin synthesis up to $3 \mathrm{~h}$ has been previously established for this cell line (Bermúdez Moretti et al, 2002).

As it has already been shown, for $3 \mathrm{~h}$ ALA exposure, the incubation with ALA for different times in the presence or absence of SA leads to the intracellular accumulation of ALA or porphyrins, respectively. To determine the effect of different intracellular ALA and porphyrin pools on ALA transport, we treated the cells with or without SA before preincubating with ALA for different times and before measuring ALA uptake (data not shown). We found that neither ALA nor porphyrin pools regulate ALA incorporation, since the initial ALA uptake rates remain constant. In addition, the presence of SA during the whole assay without changing ALA uptake demonstrates that SA does not compete for ALA uptake (Figure 1), in good agreement with the findings of Gibson et al (2001).

As it is well known that GABA is a substrate for the BETA transporters (Palacín et al, 1998), the effect of SA on GABA transport was also examined and, as expected, there is no competition between GABA and SA, and inhibition of ALA metabolisation did not affect GABA uptake either.

The higher efflux of ALA/PBG in the presence of SA (Table 3) may be a consequence of a high intracellular ALA pool due to an impairment on the conversion of ALA into PBG, which in addition, might be less diffusible than ALA.

According to temperature dependence data (Table 2), ALA transport from the cytoplasm to the extracellular medium is carried out by a diffusion process, at least after this short incubation time period. On the other hand, only active transport seems to be involved in GABA efflux. These were the expected results since they are in agreement with our previous findings (Bermúdez Moretti et al, 2002), where we demonstrated that ALA is incorporated into these cells through two different mechanisms, diffusion and an active process, while GABA uptake is not mediated by diffusion.

\section{REFERENCES}

Bermúdez Moretti M, Correa García S, Perotti C, Batlle A, Casas A (2002) $\delta$-aminolevulinic acid transport in murine mammary adenocarcinoma cells is mediated by BETA transporters. Br J Cancer 87: 471-474

Döring F, Walter J, Will J, Föcking M, Boll M, Amasheh S, Clauss W, Daniel $\mathrm{H}$ (1998) Delta-aminolevulinic acid transport by intestinal and renal peptide transporters and its physiological and clinical implications. $J$ Clin Invest 101: $2761-2767$

Dougherty T, Kaufman J, Goldfarb A, Weishaupt K, Boyle D, Mittleman A (1978) Photoradiation therapy for the treatment of malignant tumors. Cancer Res 38: $2638-2635$

Ebert P, Hess R, Frykholm B, Tschudy D (1979) Succinylacetone, a potent inhibitor of heme biosynthesis: effect on cell growth, heme content and
When we expose cells to $0.6 \mathrm{~mm}$ ALA for $15 \mathrm{~min}$, we can see that after 60 min of ALA withdrawal, all the ALA has been consumed and porphyrin synthesis cannot be further increased by extending the incubation time to $180 \mathrm{~min}$ (Table 3). Some haem enzymes such as ALA dehydratase and PBG deaminase have been postulated to be rate limiting in the production of porphyrins from ALA (Gibson et al, 1998, 2001). However, under our conditions of short ALA exposure, ALA availability is limiting tetrapyrrole formation.

GABA is a competitor for ALA uptake and a putative competitor for ALA efflux. In an attempt to diminish ALA efflux, and consequently, increase porphyrin synthesis, we exposed the cells to equimolar GABA concentrations, after ALA preloading (Table 4). However, neither ALA nor GABA affected ALA efflux, instead the latter competed for ALA uptake. These data reinforce the hypothesis that ALA efflux is mainly mediated by a diffusion process, whereas ALA uptake even at short incubation times, is at least in part mediated by a saturable transport mechanism.

Porphyrin release is kept to $15 \%$ independent of the incubation times. This is a typical release of PPIX to a medium without serum, and it has been previously reported by Fukuda et al (1993b) and Iinuma et al (1994). Although it is not known whether this loss is passive or whether it involves an active transport process (Fukuda et al, 1993a, b), the different efflux rates observed by Iinuma et al (1994) using different cell lines, suggest that the mechanism is not simply mediated by diffusion. However, characterisation of the mechanisms of PPIX efflux exceeds the aims of this paper.

This is the first study describing ALA efflux in a non-neural cell line. We attempted to diminish such efflux to improve ALA availability with the aim of increasing PDT efficacy. However, we found that until $15 \mathrm{~min}$ after preloading with ALA, a diffusion process mediates efflux, and we could not modulate it by employing putative competitors. Nevertheless, further studies should be carried out to explore the possibility of inhibiting ALA efflux at longer incubation times.

The design of new nondiffusible ALA derivatives would be an approach to overcome the disadvantage of ALA efflux. In this regard, taking into account the fact that GABA does not efflux from cells, the structural differences between ALA and GABA could be further exploited.

\section{ACKNOWLEDGEMENTS}

This research was supported by grants from Argentine National Research Council (CONICET) (PIP 4108/96 and 105508-99-00), the Science and Technology Argentine Agency (STAA) (PICT 0500000-01861) and the Association for International Cancer Research (AICR-UK, 98-6). AB, SCG, MBM and AC hold the posts of Superior, Associate and Assistant Researchers at the CONICET. $\mathrm{CP}$ is a 'Carrillo-Oñativia' fellow from the Ministerio de Salud Pública, Argentina. delta-aminolevulinic acid dehydratase activity of malignant murine erythroleukemia cells. Biochem Biophys Res Commun 88: 1382 - 1390

Fukuda H, Casas A, Chueke F, Paredes S, Batlle A (1993a) Photodynamic action of endogenously synthesized porphyrins from aminolevulinic acid, using a new model for assaying the effectiveness of tumoral cell killing. Int J Biochem 25: 1395-1398

Fukuda H, Batlle A, Riley P (1993b) Kinetics of porphyrin accumulation in cultured epithelial cells exposed to ALA. Int $J$ Biochem 25: $1407-1410$

Gibson S, Cuprkis D, Havens J, Nguyen M, Hilf R (1998) A regulatory role for porphobilinogen deaminase (PBGD) in 5-aminolevulinic acid (5-ALA)-induced photosensitization? Br J Cancer 77: 235-243 
Gibson S, Havens J, Metz L, Hilf R (2001) Is $\delta$-aminolevulinic acid dehydratase rate limiting in heme biosynthesis following exposure of cells to aminolevulinic acid? Photochem Photobiol 73: $312-317$

Iinuma S, Farshi S, Ortel B, Hasan H (1994) A mechanistic study of cellular photodestruction with 5-aminolevulinic acid-induced porphyrin. $\mathrm{Br} J$ Cancer 70: $21-28$

Kennedy J, Pottier R, Pross G (1990) Photodynamic therapy with endogenous protoporphyrin IX: basic principles and present clinical experience. J Photochem Photobiol B 6: 143-148

Kriegmair M, Baumgartner R, Knuechel R, Stepp H, Hofstadter F, Hofstetter A (1996) Detection of early bladder cancer by 5 -aminolevulinic acid induced porphyrin fluorescence. I Urol 155: 105-110

Malik Z, Djaldetti M (1979) 5-aminolevulinic acid stimulation of porphyrin and hemoglobin synthesis by uninduced Friend erythroleukemic cells. Cell Differ 8: $223-233$

Mauzerall M, Granick S (1956) The occurrence and determination of 5-aminolevulinic acid and porphobilinogen in urine. J Biol Chem 219: $435-437$

Navone N, Frisardi Resnik E, Batlle A, Polo C (1988) Porphyrin biosynthesis in human breast cancer. Preliminary mimetic in vitro studies. Med Sci Res 16: 61-62

Navone N, Polo C, Frisardi A, Batlle A (1991) Mouse mammary carcinoma PBGase and hydroxymethylbilane synthetase. Comp Biochem Physiol B 98: $67-71$
Novotny A, Xiang J, Stummer W, Teuscher N, Smith D, Keep R (2000) Mechanisms of 5-aminolevulinic acid uptake at the choroid plexus. $J$ Neurochem 75: $321-328$

Palacín M, Estévez R, Bertran J, Zorzano A (1998) Molecular biology of mammalian plasma membrane amino acids transporters. Physiol Rev 78: $969-1054$

Pottier R, Chow Y, La Plante J-P, Truscott T, Kennedy J, Beiner L (1986) Non-invasive technique for obtaining fluorescence excitation and emission spectra in vivo. Photochem Photobiol 44: 679-687

Rimington C (1966) Porphyrin and haeme biosynthesis and its control. Acta Med Scand 176: $11-24$

Rud E, Gederaas O, Hogset A, Berg K (2000) 5-aminolevulinic acid, but not 5-aminolevulinic acid esters, is transported into adenocarcinoma cells by system BETA transporters. Photochem Photobiol 73: $164-169$

Sinna A, Kennedy J, Balkeslee D, Robertson D (1981) Experimental porphyric neuropathy: a preliminary report. Can J Neurol Sci 8: $105-114$

Werbajh SE, Urtreger AJ, Puricelli LI, de Lustig ES, Bal de KierJoffe E, Kornblihtt AR (1998) Downregulation of fibronectin transcription in highly metastatic adenocarcinoma cells. FEBS Lett 440: 277-281

Whitaker C, Battah S, Forsyth M, Edwards C, Boyle R, Matthews K (2000) Photosensitization of pancreatic tumour cells by 5 -aminolevulinic acid esters. Anti-Cancer Drugs Desi 15: $161-170$ 